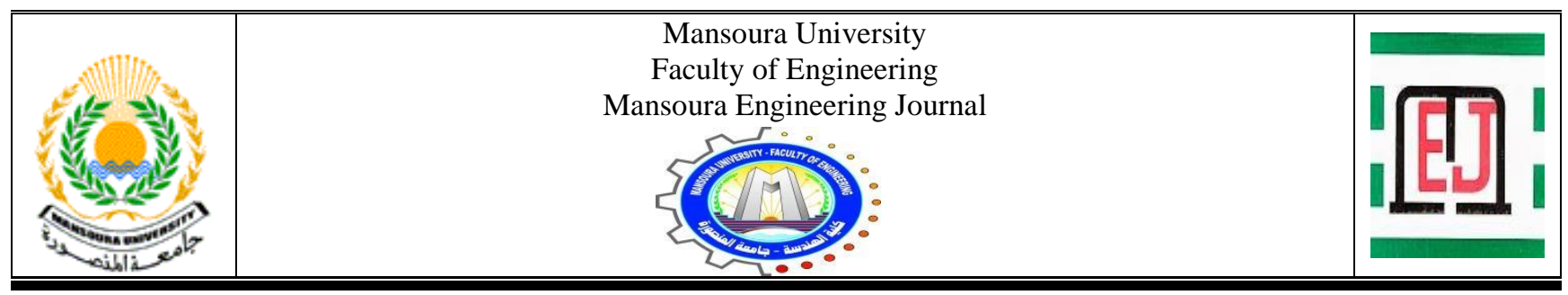

\title{
Re-Studying Rosetta City as a Cultural Landscape, a Step for Registration on the World Heritage List
}

\author{
Basma Shaheen*, Mai Wahba Madkour, Shahira Sayed Hasan and Ahmed Abd-Elwahab
}

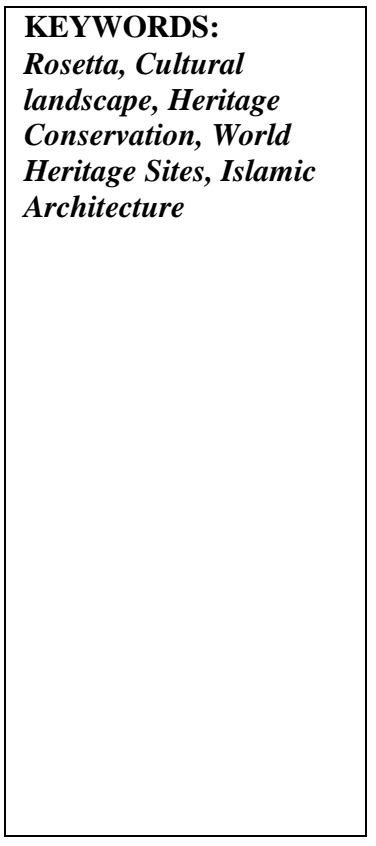

Abstract: Cities are dynamic organisms. There is no 'historic' city in the world that has retained its 'original' character destined to change with society itself. Therefore, it is necessary to make various efforts to preserve historical cities' identity in sustainable ways. The city of Rosetta is considered one of the most important historical cities, which is classified as the second-largest Egyptian city containing Islamic monuments after historic Cairo. Rosetta is best known for the Rosetta stone, which was discovered in the Qayitbay castle in 1799 and suffered from many problems related to heritage conservation and management. The research problem has focused on setting a new hypothesis regarding Rosetta as a cultural landscape and applying the criteria of universal importance to it. The reasons that influence in shaping the city's distinctive character will be discussed, which qualifies it to run for registration on the World Heritage List as a cultural landscape. This hypothesis may increase Rashid's national importance and thus increase opportunities for development and investment, which may raise the standard of the living city. The research methodology was based on two main axes:

1. Analytical approach: It includes a study on the effects of the natural and historical components of Rashid on making this city a cultural landscape area.

2. Practical analytical approach: It includes applying international standards for Rashid to be registered on the World Heritage List. The results are summarized in finding definitive evidence that Rashid is a cultural landscape area; also, some recommendations were added.
Received: (15 July, 2021) - Revised: (04 September, 2021) - Accepted: *Corresponding Author: Basma Shaheen, Researcher at Farouk Elbaz Center of Sustainability and Future Studies (FSCSFS), British University in Egypt (BUE), Cairo, Egypt. (email: Basma.shaheen89@gmail.com)

Mai Wahba Madkour, Associate Professor, Department of Architecture, Faculty of Engineering, Tanta University (e-mail: mai_madkour@feng.tanta.edu.eg).

Shahira Sayed Hasan, Professor, Department of Architecture, Faculty of Engineering, Tanta University (e-mail: shira111@yahoo.com).

Ahmed Abd-Elwahab, Professor, Department of Architecture Faculty of Engineering, Tanta University (e-mail: ahmed.rezk@f-eng.tanta.edu.eg).

\section{INTRODUCTION}

7 HE World Heritage sites are landmarks or areas that have been nominated by the World Heritage Committee of the United Nations Educational, Scientific, and Cultural Organization (UNESCO) for inclusion in the World Heritage Sites Program, which UNESCO manages. These features can be natural, like forests and mountain ranges, or man-made, like buildings and cities, or a combination of the two as a mixed. The Convention on the Protection of the World Cultural and Natural Heritage launched this program adopted at the UNESCO General Conference on November 16, 1972. Since the agreement was 
signed, 189 countries have ratified it. The program's goal is to categorize, name, and preserve cultural and natural sites of particular interest to humanity. Under the terms of this agreement, the sites participating in this program will receive financial assistance under certain conditions (1).

Under the terms of this agreement, the sites participating in this program will receive financial assistance under certain conditions. Check Table 1.

TABLE 1

WORLD HERITAGE LIST PROPERTIES IN2018, SOURCE: (2).

\begin{tabular}{l||c||c||c||c}
\multirow{2}{*}{ Property } & $\begin{array}{c}\text { Cultural } \\
\text { Sites }\end{array}$ & $\begin{array}{c}\text { Natural } \\
\text { Sites }\end{array}$ & $\begin{array}{c}\text { Mixed } \\
\text { Sites }\end{array}$ & Total \\
\cline { 2 - 4 } & 845 & 209 & 38 & 1092
\end{tabular}

\section{A. The World Heritage Sites in Egypt}

Egypt has a great deal of heritage property that dates back to civilization and rich history. It has led to registration on the World Heritage List. Still, unfortunately, due to stakeholders' failure to make the necessary efforts and Egypt's economic and political conditions, there is a scarcity of Egyptian sites on the list (3) . Nevertheless, seven Egyptian heritage sites are listed on the World Heritage list and the official website of UNESCO. Check Figure 1.

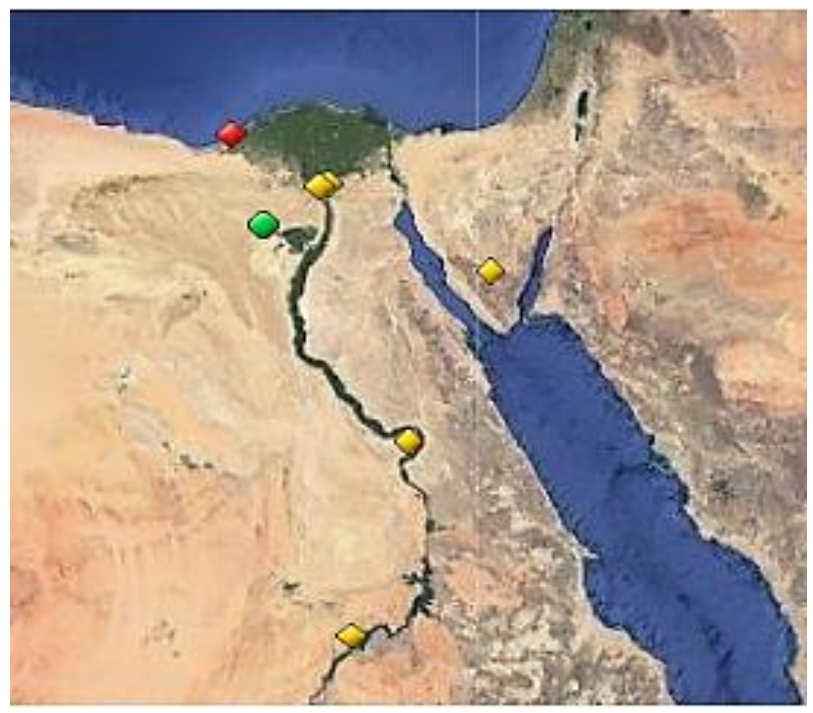

Figure 1- (The World Heritage Sites in Egypt 2018), (4)

Moreover, there are also 33 Egyptian archaeological sites on the Tentative List (2).

When a country wishes to nominate one of its monuments or properties, the nomination process begins; first, the state stores its unique cultural and natural properties.

This is known as the initial Tentative List of World Heritage Sites, and it is an essential process because the country should not nominate sites that are not on its initial list. The country representatives choose antiquity from this list to include in the nomination file (5). The World Heritage Center assists in the preparation of these files.

In shedding light on the city of Rosetta, it was discovered that it was listed for registration as a cultural heritage site on the UNESCO site. However, it has yet to be included on the list due to the responsible authorities' failure to submit files related to the city's nomination. Cities that have expressed an interest in participating in the registration process (4).

The majority of the studies on the city of Rosetta in heritage preservation have been concerned with researching existing heritage models.

Some methods of preserving buildings and studies discussed problems related to rationally preserving heritage, as well as the damage and dangers that may threaten the historical city. In addition to some projects adopted by responsible institutions in Rosetta and government agencies to develop the town of Rosetta (6). However, most studies and research and future development projects for Rosetta did not consider the city's inclusion on the World Heritage List to be an excellent opportunity for the city's comprehensive, higher, and better development. The International Council of Monuments and Sites and the International Union for Conservation of Nature evaluate the file at this point. The file is sent to the World Heritage Committee, which meets once a year to decide whether the nominated properties should be added to the World Heritage List. This decision is sometimes delayed by requesting more information from the country that recommends the site. There are ten selection criteria; to be listed, a nominated site must meet at least one of them (5).

It should be noted that even though Rosetta existence on the Tentative List as a cultural heritage, as it meets three of ten criteria for the outstanding universal value assessment, which are (ii)(iv)(v) (4). However, Rosetta was never registered on the World Heritage List due to the heritage authorities' negligence.

\section{B. Types of heritage according to UNESCO classifications}

\section{Cultural landscape:}

There are various definitions for the concept of cultural landscape, such as Parks Canada's definition, which provided a modern description of a specific type of cultural landscape, one that is extremely relevant to World Heritage in the subject and close to the spirit of World Heritage itself (7):

"An aboriginal cultural landscape is a place valued by an aboriginal group (or groups) because of their long and complex relationship with that land. It expresses their unity with the natural and spiritual environment. It embodies their traditional knowledge of spirits places, land uses, and ecology" (8). Check Figure 2

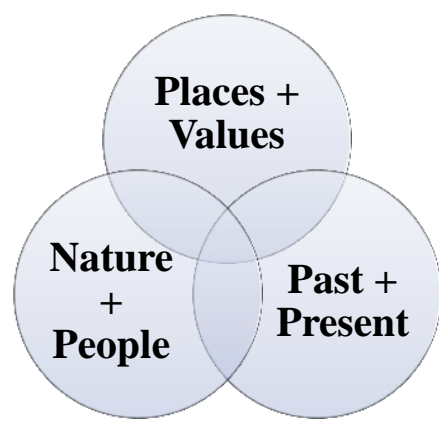

Figure 2 (The three aspects of Cultural Landscape) (7)

The exact meaning has been confirmed in the World Heritage Convention's definition of the cultural scene, which states: 
Cultural landscapes are cultural properties and represent the "combined works of nature and man" designated in Article 1 of the Convention. They depict the evolution of human society and settlement over time due to the physical constraints or opportunities presented by their natural environment, as well as successive social, economic, and cultural forces, both external and internal (8)".

Cultural landscapes are classified into three types under the World Heritage Convention's concept of heritage preservation (5). The three categories adopted by the Committee in 1992 and included in Paragraph 39 of the Operational Guidelines (2002) are described in Appendix 2. The Operational Guidelines were revised in 2005 and again in 2008, and all categories of heritage were included in Annex III of the Operational Guidelines.

The text on cultural landscapes, on the other hand, remained unchanged. These categories were shown in Table 2 as mentioned (9).

TABLE 2

THE THREE CATEGORIES OF WORLD HERITAGE CULTURAL LANDSCAPES (9)

\section{国}

Extract from the operational guidelines for the implementation of the World Heritage Convention

1 The most easily identifiable is the clearly defined landscape designed and created intentionally by man. This embraces garden and parkland landscapes constructed for aesthetic reasons, which are often (but not always) associated with religious or other monumental buildings and ensembles.

2 The second category is the organically evolved landscape. This results from an initial social, economic, administrative, and/or religious imperative and has developed its present form by association with and in response to its natural environment. Such landscapes reflect that process of evolution in their form and component features. They fall into two sub-categories:

- A relict (or fossil) landscape is one in which an evolutionary process came to an end at some time in the past, either abruptly or over a period. Its significant distinguishing features are, however, still visible in material form.

- A continuing landscape retains an active social role in contemporary society closely associated with the traditional way of life and in which the evolutionary process is still in progress. At the same time, it exhibits significant material evidence of its evolution over time.

3 The final category is the associative cultural landscape. The inclusion of such landscapes on the world heritage list is justifiable by virtue of the natural element's powerful religious, artistic, or cultural associations rather than material cultural evidence, which may be insignificant or even absent.

Rosetta has been nominated for inclusion on the World Heritage List as a cultural heritage because it meets three global significance criteria. First, t physical aspect of the city's archaeological monuments, such as mosques and archaeological houses, was considered while ignoring the natural and human factors that contributed to creating this special and unique type of Rosetta heritage (4).

This topic is discussed in the research to better understand the relationship between architecture in place, surrounding nature, the rational person, and the nature of his activities that were affected by local architecture.

\section{Criteria for the assessment of Outstanding Universal Value:}

The Committee considers a property to have Outstanding Universal Value if it meets one or more of the following criteria. Table 3 shows the nomination criteria( 8$)$.

TABLE 3

CRITERIA FOR THE ASSESSMENT OF OUTSTANDING UNIVERSAL VALUE (8)

\begin{tabular}{|c|c|}
\hline CRITERIA & $\begin{array}{c}\text { Extract from The Operational Guidelines for The } \\
\text { Implementation of the World Heritage Convention: } \\
\text { Criteria (Paragraph 77) }\end{array}$ \\
\hline I. & Represent a masterpiece of human creative genius; or \\
\hline II. & $\begin{array}{l}\text { Exhibit an important interchange of human values, over a } \\
\text { span of time or within a cultural area of the world, on } \\
\text { developments in architecture or technology, monumental } \\
\text { arts, town-planning, or landscape design; or }\end{array}$ \\
\hline III. & $\begin{array}{l}\text { Bear a unique or at least exceptional testimony to a cultural } \\
\text { tradition or to a civilization which is living, or which has } \\
\text { disappeared; or }\end{array}$ \\
\hline$I V$. & $\begin{array}{l}\text { Be an outstanding example of a type of building or } \\
\text { architectural or technological ensemble or landscape that } \\
\text { illustrates (a) significant stage(s) in human history; or }\end{array}$ \\
\hline $\bar{V}$. & $\begin{array}{l}\text { Be an outstanding example of a traditional human } \\
\text { settlement or land-use which is representative of a culture } \\
\text { (or cultures), especially when it has become vulnerable } \\
\text { under the impact of irreversible change; }\end{array}$ \\
\hline VI. & $\begin{array}{l}\text { Be directly or tangibly associated with events or living } \\
\text { traditions, with ideas, or with beliefs, with artistic and } \\
\text { literary works of outstanding universal significance (the } \\
\text { Committee considers that this criterion should justify } \\
\text { inclusion in the List only in exceptional circumstances and } \\
\text { in conjunction with other criteria cultural or natural); }\end{array}$ \\
\hline VII. & $\begin{array}{l}\text { Contain superlative natural phenomena or areas of } \\
\text { exceptional natural beauty and aesthetic importance; or }\end{array}$ \\
\hline VIII. & $\begin{array}{l}\text { Be outstanding examples representing major stages of } \\
\text { earth's history, including the record of life, significant on- } \\
\text { going geological processes in the development of } \\
\text { landforms, or significant geomorphic or physiographic } \\
\text { features; or }\end{array}$ \\
\hline$I X$. & $\begin{array}{l}\text { Be outstanding examples representing significant ongoing } \\
\text { ecological and biological processes in the evolution and } \\
\text { development of terrestrial, freshwater, coastal, and marine } \\
\text { ecosystems and communities of plants and animals; or }\end{array}$ \\
\hline$X$. & $\begin{array}{l}\text { Contain the most important and significant natural habitats } \\
\text { for in-situ conservation of biological diversity, including } \\
\text { those containing threatened species of outstanding universal } \\
\text { value from the point of view of science or conservation; }\end{array}$ \\
\hline
\end{tabular}

\section{Problem Overview \& Aims}

Rashid or Rosetta was regarded as one of Egypt's leading nautical entrances due to the significant presence of commercial exchange in Rosetta's ports on the Mediterranean Sea and the Nile River. During the Ottoman era, Rosetta's buildings were constructed from many pieces that dated back to previous eras' heritage, such as pharaonic, Phoenician, Romanian, and Greek origins, representing the current Rosetta's heritage. (10).

In general, the city suffers many physical, environmental, economic, and social problems. However, the most important of these is the desecration of the Nile Riverside and traffic jams such as the railway line and station, which causes many environmental issues. Moreover, the city is struggling with urban infringement on agricultural land, the intersection of cemeteries with residential areas, the deterioration of the city's infrastructure, and the spread of many slums (11).

Focusing on heritage issues, Rachid suffers deterioration in 
the touristic side due to the dramatic disregard of heritage buildings and their surrounding sites; moreover, the neglect of heritage areas and infrastructure constitutes a significant threat to heritage preservation plans (3).

On the other side, the issuance of the Ministerial Decree No 113 of 1986 focused on the necessity of exploiting historical elements of the city to become a part of the Egyptian and international map of tourism. However, the absence of optimum exploitation of the touristic town, commensurate with its heritage and geography, could be considered the main reason that the city isn't included in the world tourist map despite its size and importance of its urban and architectural heritage (12).

Rosetta's Problem could be remarked by the missing optimization of the city's natural and heritage resources and documentation of the minus points of study that proves the similarities between Rosetta's heritage and natural areas and the cultural landscape classification of the World Heritage Convention of UNESCO. This hypothesis may change the city's future development plans to the perspective of upgrading and maintaining urban surroundings and not by dealing with monumental buildings, which also leads to an increase in the investment opportunities for economic development and tourism and increase the national importance of the city.

At last, the research sheds light on the combability of Rosetta's city and the standards of cultural landscape standards set by the World Heritage Convention. Therefore, Rosetta could be considered a cultural landscape area and a cultural heritage, which would change the pattern and ways of preserving the heritage to be at the level of the city as a whole and not only the traditional buildings or streets only.

\section{RESEARCH METHODOLOGY}

The methodology relied on analyzing the city of Rosetta through 3 phases that represent the three elements that define the concept of the cultural landscape, which are:

- the surrounding nature

- the human culture at that time

- the urban and architectural product of distinctive value in that geographical location.

The analysis also demonstrates the mutual intersection effects between the human being and his surrounding environment, which created the cultural heritage in this earth's spot. And even research the geographical location of Rosetta and Islamic culture back then's the role in forming Rosetta's current identity through its historical buildings and residents' activities, which led to the fact that Rosetta is a result of human culture mixture with nature.

\section{Case study Analysis: Rosetta City}

\section{A. Location}

Rosetta city is considered a port city near the Mediterranean coast of Egypt. It is located on the West side of the Nile's western side branch (Rashid branch), $65 \mathrm{~km}$ from
Alexandria city. This site made Rosetta one of the main exits of the Delta, where the Rosetta branch was an essential means of river transportation, especially in the Middle Ages. The city is in the northern region of Egypt; therefore, it was characterized by the abundance of its natural resources, like the northern coast, Nile River, agricultural land, and sand dunes. Currently, Rosetta is located within Al Beheira, one of the largest governors in terms of area. It consists of 15 administrative centers, one of which is Rosetta. Moreover, Rashid Center consists of one city is Rosetta, and 16 villages (14). Check Figure 3

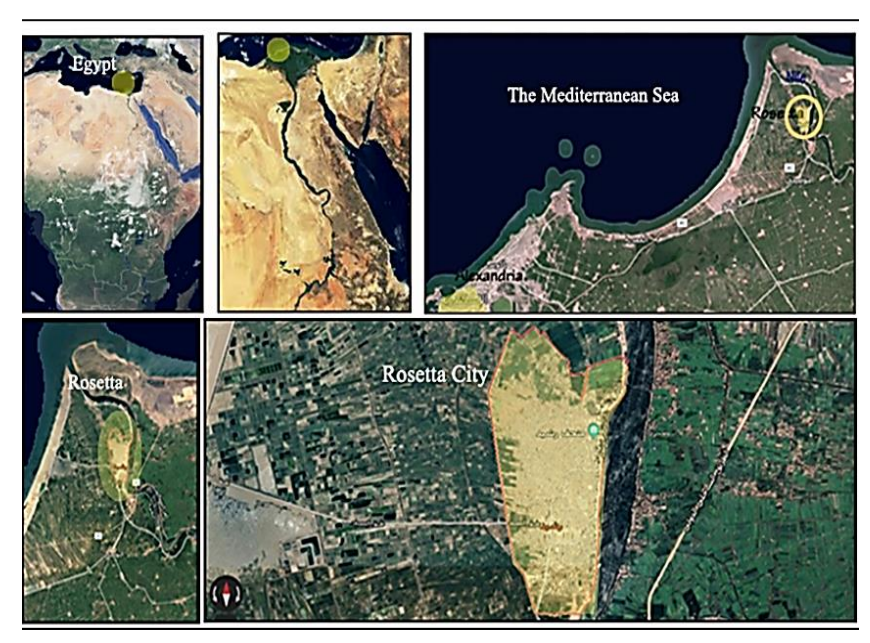

Figure 3 (Location Analysis of Rosetta) (15)

\section{B. The geographical change of the city over time}

Rosetta's birth, growth, and demise are inextricably linked to the Nile River and the Mediterranean Sea. The town is situated on one of the Nile's main branches (the Rosetta branch), close to where it empties into the Mediterranean. Whether from the Nile or the Mediterranean, wateras shaped the city's surroundings, bringing it closer or further away from the coast (16).

Rosetta came the closest to the coast in the 16th century.

The Nile's sediments continuously expanded the land on the coast into the sea from the 17th to the 18th centuries. However, with the construction of the Mahmoudia Canal in 1820 , this phenomenon began to reverse in the nineteenth century.

Later, in 1965, the High Dam was built, which reduced the amount of sediment deposited by the river, pushing the coast back 10 kilometers (13). Water has also influenced the evolution of the city. For hundreds of years, the Nile has been Rosetta's urban planner, providing it with strips of land that have formed the cityscape and streets from Zaglul (the market street) to the corniche. The sediments left on the riverbank have assisted Rosetta in relieving urban expansion pressure in response to the city's growing economic needs.

River sediments were also a frequent cause of town abandonment; when sand blocked circulation in the Rosetta branch, the city was abandoned entirely, and people relocated to the nearby village Fowa (17). Check Figure 4. 

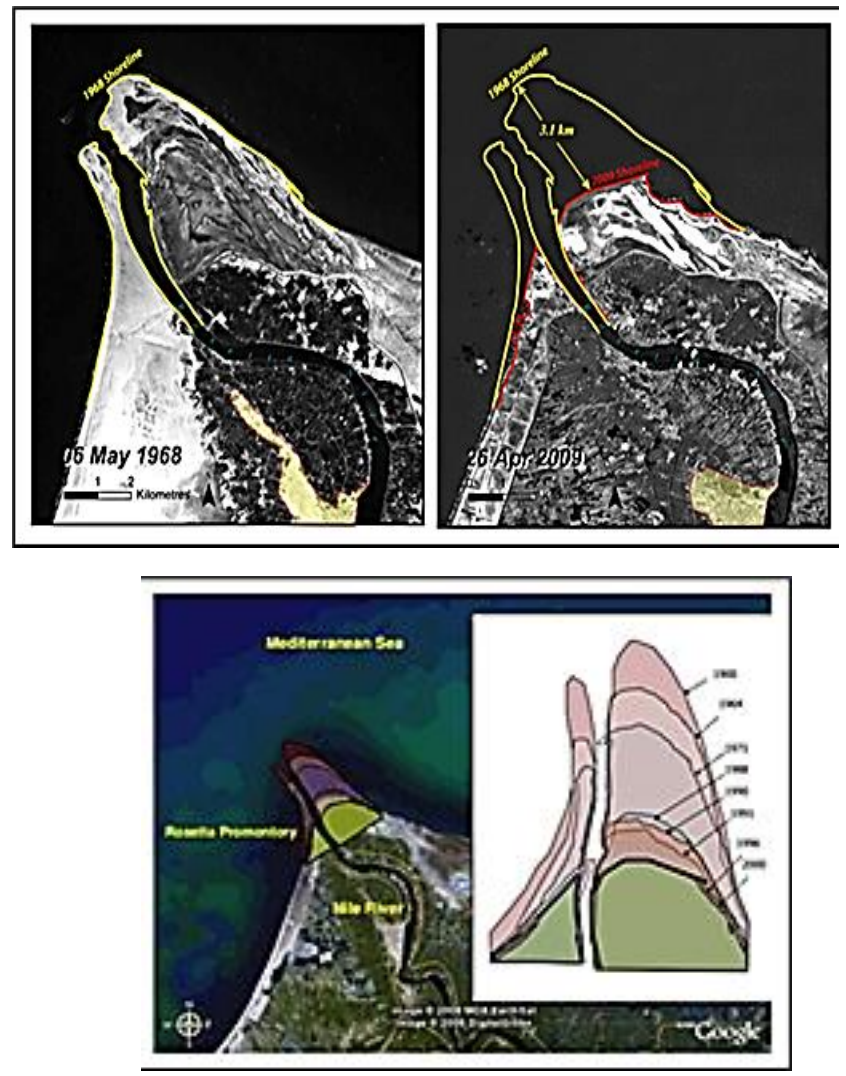

Figure 4 (The geographical change of the city over time (17))

\section{Geographical Location and The Historical Identity of the} City:

\section{The military and defensive identity of the city}

The city's location on the Mediterranean Sea and at the entrance to the Nile River (Fig. 5) has contributed significantly to the increased interest in its immunization.

In the nineteenth century, King Merneptah (1234-1224 BC) built fortifications in Rosetta to defend the country against pirate attacks at sea, demonstrating the danger to Egypt's western borders and coasts (16). Check Figure 5.

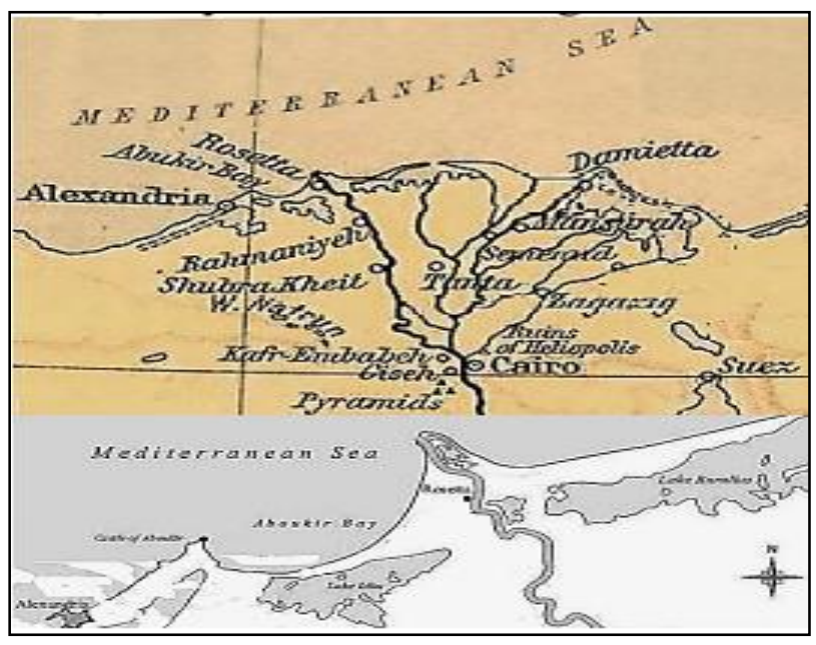

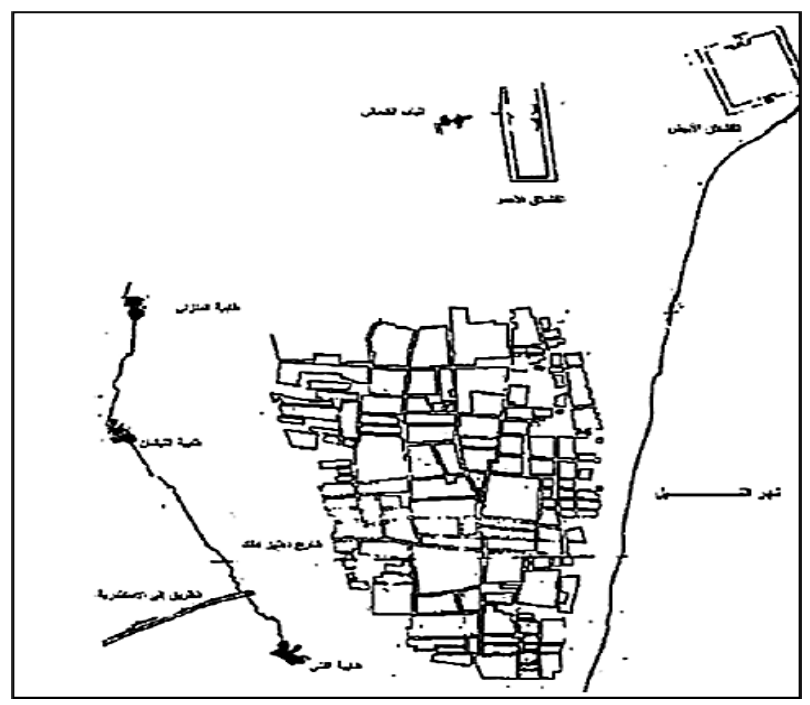

Figure 5 (The military and defensive urban shape of the city) (16)

Rosetta was declared a war zone. In times of conflict, Rabat was the epicenter of this emerging city. The war became apparent in its planning, which was used as a food supplier. The Nile River served as a link between Rosetta and the country's cities, and its proximity to the Mediterranean aided in providing access to the outside world. The city emphasized the importance of immunization to protect its existence and advance its urbanization. Whatever the reasons for its inception, trade played a critical role in its development (17). Some structures whose remains are still present in Rosetta, such as Qaitbay Citadel and the remains of Tal Abu Mandour Abu Elreesh Gate, have also revealed characteristics of the war city. Check Figure 6 and Figure 7.
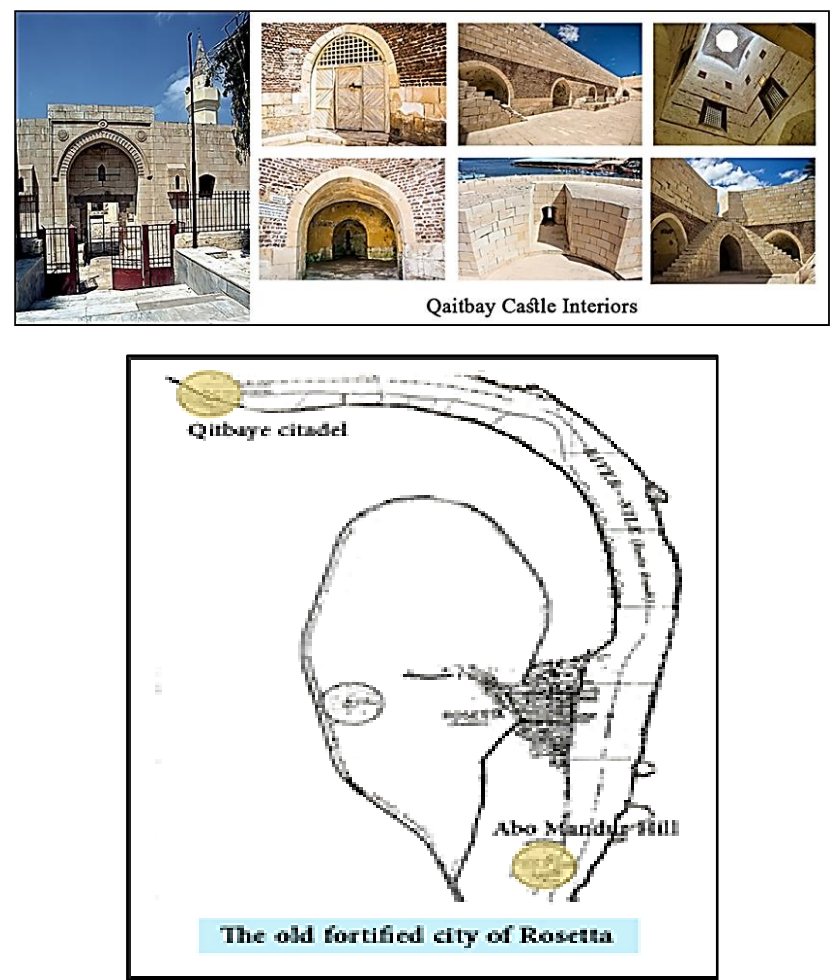

Figure 6 (Qaitbay Castle location) (16) 


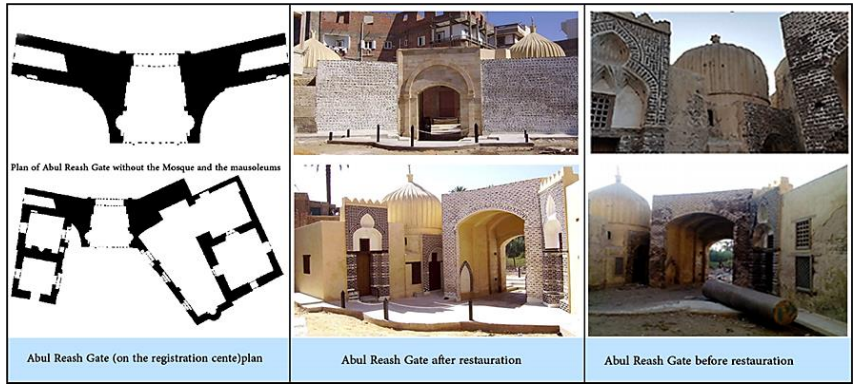

Figure 7 ( Abu Elreesh Gate (16))

The commercial identity of the city: The Nile River was one of the means of communication between Rosetta and the country's cities. Its proximity to the Mediterranean aided in providing access to the outside world. That was one of the reasons for the growth of commerce and urbanization. The city's growth and prosperity were inextricably linked to its military location.

The city was the first to establish the Abbasid Ribat (fort), the city's nucleus, built around military installations, particularly during the Mamluk era, after the external threat increased.

However, the transformation occurred during the Ottoman era, when Rosetta first became a commercial city. The Ottomans considered defensive methods of planning, particularly in streets and building entrances. Buildings that serve the new transformation, such as agencies, markets, rice circles, and various industrial facilities, have been established. It has grown in population density (18).

Fishing is one of the activities that characterize Rosetta's city, which has natural resources, many fishing boats (approximately 450 boats), and 22 fish farms.

Many fish cages produce approximately 400 tons of fish per year, with a large portion exported to the Gulf States. Check Figure 8. According to some studies, the number of fishing employees is estimated to be 1077, accounting for 4.9 percent of all workers in Rosetta in 2006; the endemic factor of this activity is 2.6 , making it a leading activity (12).
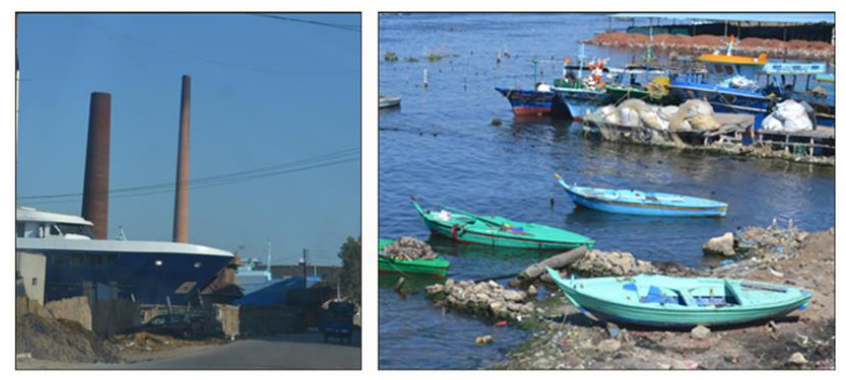

Figure 8 (shipbuilding industry and fishing craft (Researcher))

Naturally, the residents of Rosetta's city rely on the surrounding environment to build their homes. The old buildings were to be demolished in order to repair the damage done to the former residents. Old structures were used as a source of building materials in new structures. Mud was used to make building materials, as was lime, red, and occasionally gypsum. The roofing was done by wood or by building with cross vaults or domes (12).

\section{The Tourist identity of the city:}

- Discovery of the Rosetta Stone: The Rosetta Stone is considered one of the most important Egyptian artifacts, as it holds the key to understanding Egyptian hieroglyphs. Soldiers in Napoleon's army discovered the Rosetta Stone in 1799 while digging foundations and a fortress near the city of Rosetta (Rachid). Following Napoleon's defeat, the stone, along with other antiquities discovered by the French, became British property under the Treaty of Alexandria (1801) (20) .

- As a result, the stone's original home is Rosetta's city, which is reason enough to make it the face of tourists and archaeologists interested in history and archaeology.

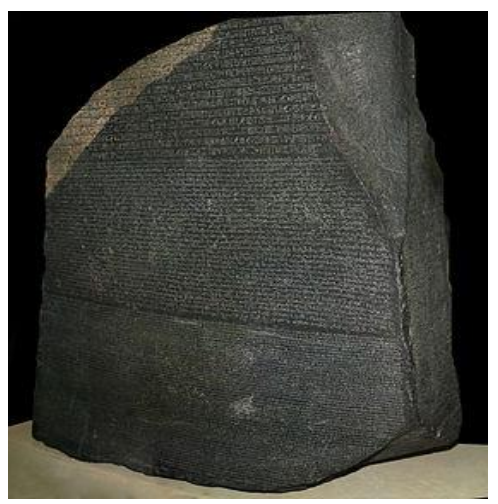

Figure 9 (Rosetta stone (Museum, 1802))

- Water tourism: its geographical location on the Nile and the sea have created recreational tourism, such as Nile tourism, yachting, and watercraft tourism.

- Sand dunes: There are many sand dunes located between Rosetta and Edku in the western part of the Nile Delta, which are distinguished by their beauty and the possibility of doing some recreational activities for visitors. Also, sand dunes are considered safe for the city from sea-level rise. However, the outcome of potential sea-level rise is serious; erosion Problems are expected to be exacerbated, and vast land and property areas would be lost. Thus, the protection and preservation of the remaining dunes in the study area are vital requirements for shore protection (17).

- The palm Zone: Rashed is characterized by the presence of a massive area for palms, estimated at one million palm trees, which represents $10 \%$ of the real palm trees in Egypt. But this botanical forest is underutilized, whether on the tourist or economic level, but this does not negate its importance and what it adds to the city's green identity, so the town of Rosetta is called the country of a million palm trees. Therefore it is a distinctive element of the city, and plans can later be drawn up to preserve this area from the oppressive cutting of palm trees (RUSPS, 2006). 


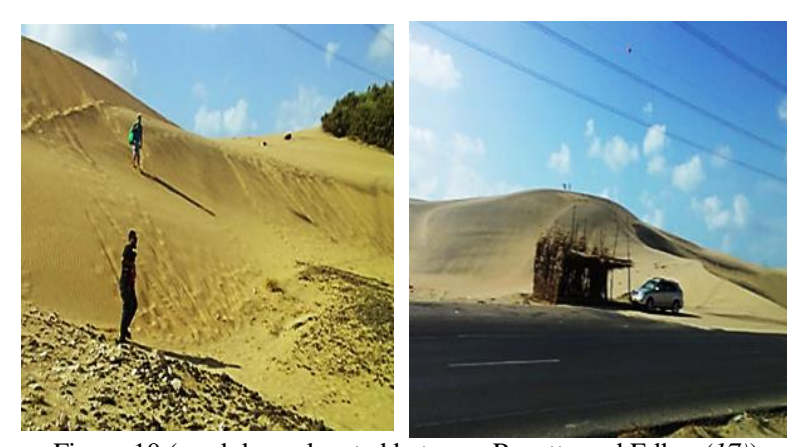

Figure 10 (sand dunes located between Rosetta and Edku (17))
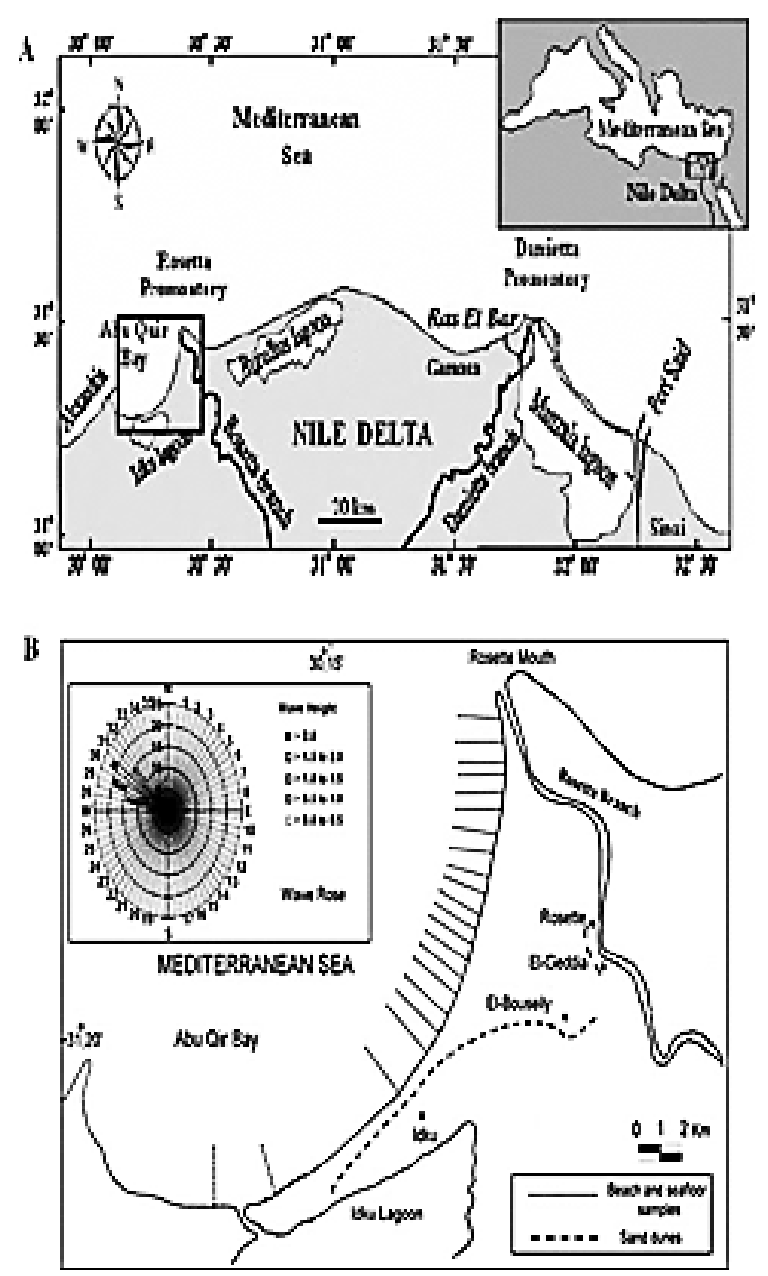

Figure 11 (sand dunes location between Rosetta and Edku (17))

By considering it a natural vegetable reserve without maintaining process, which is regarded as a threat to some industries related to it, such as dates' production. These industries are estimated annually at about 18 million Egyptian pounds. In addition, some handicrafts are related to palm trees, such as cages, furniture, and fiber ropes. The additional job opportunities it provides are valued. Check Figure 11. This sector, after its development, with about 958 new job opportunities during the period from 2006 to 2027, according to the general strategic plan for the city of Rosetta (Gopp, 2006).

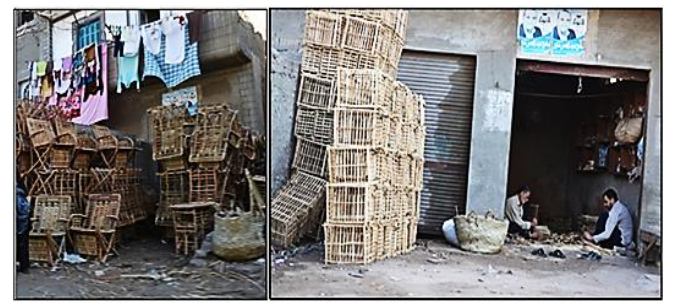

Figure 12 (Industries based on palms in Rosetta (Researcher))

\section{Rosetta Cultural Heritage:}

Houses, mosques, a mill, and a hammam (Turkish bath). have all been preserved as reminders of Rosetta's golden age. With 38 registered historical monuments and sites, it is Egypt's second richest town in terms of Islamic monuments after Cairo. (10). Rosetta's significance as a tourist destination was announced in Law 113 in 1986. The Supreme Council for Antiquities then began the process of preserving historic buildings in the city. The Rapid Urban Sector Profiling for Sustainability (RUSPS) study also addressed Rosetta's heritage conservation. Through consultative processes, this study took a participatory approach (12). The General Organization for Physical Planning recognized the importance of implementing policies and programs to promote heritage conservation and development, as requested in Construction Law 119 in 2008, followed by Rosetta's official announcement as an open-air museum in 2007 (11). The following table shows a collection of examples of the heritage buildings in Rosetta city and the period during which they were built. Check Figure 12.

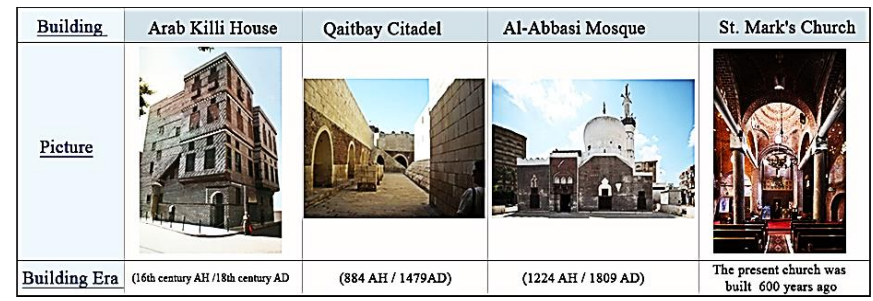

Figure 13 (examples of the heritage buildings in Rosetta (12))

Rosetta currently includes 22 houses, twelve mosques, a public bath, a mill, a castle, and a city gate. These mosques and heritage houses are listed in the following tables. Check Tables 4,5,6.

TABLE 4

(List OF Heritage Mosques In Rosetta (RESEARCHER))

\begin{tabular}{|c|c|c|c|}
\hline No. & Mosque Name & Construction Date & Location \\
\hline 1 & Wafya Al-Samet & $1174 \mathrm{AH}-1760 \mathrm{AD}$ & Zaghloul Street \\
\hline 2 & Al-Moshed Blnor & $1178 \mathrm{AH}-1764 \mathrm{AD}$ & Sedi Al-Nor Street \\
\hline 3 & Al-Mahalli & $1134 \mathrm{AH}-1722 \mathrm{AD}$ & Public Market Street \\
\hline 4 & Al-Gendi & $1132 \mathrm{AH}-1720 \mathrm{AD}$ & Public Market Street \\
\hline 5 & Domaksees & $1116 \mathrm{AH}-1714 \mathrm{AD}$ & Ali Al-garem Street \\
\hline 6 & Al-Abassi & $1224 \mathrm{AH}-1809 \mathrm{AD}$ & Al -Kornish street \\
\hline 7 & Al-Orabie & $1219 \mathrm{AH}-1804 \mathrm{AD}$ & Dehliez Al-Molk street \\
\hline 8 & Al-shaikh Qandel & 12th century $\mathrm{AH}$ & Al-shaikh Qandel street \\
\hline 9 & Al-Basha & 12 th century $\mathrm{AH}$ & $\begin{array}{l}\text { Wekalah Al-Qonsol } \\
\text { street }\end{array}$ \\
\hline 10 & Zaghloul & $985 \mathrm{AH}-1577 \mathrm{AD}$ & Zaghloul Street \\
\hline 11 & Abo Mandour & $1312 \mathrm{AH}-1897 \mathrm{AD}$ & Abo Mandour Street \\
\hline 12 & Al-Shaikh Toqa & $1133 \mathrm{AH}-1721 \mathrm{AD}$ & $\begin{array}{l}\text { Tawahen Al-Talayet } \\
\text { street }\end{array}$ \\
\hline
\end{tabular}


TABLE 5

(LIST OF HERITAGE HOUSES IN ROSETTA (RESEARCHER))

\begin{tabular}{|c|c|c|c|}
\hline No. & House Name & Construction Date & Location \\
\hline 1 & Asfour House & $1168 \mathrm{AH}-1754 \mathrm{AD}$ & Al-Mahaly Street \\
\hline 2 & $\begin{array}{ll}\text { Al- } & \text { Baqroly } \\
\text { House }\end{array}$ & $1131 \mathrm{AH}-1718 \mathrm{AD}$ & Ali Al-garem Street \\
\hline 3 & Farahat House & 12th century $\mathrm{AH}$ & Fehama street \\
\hline 4 & $\begin{array}{l}\text { Haseba Galal } \\
\text { House }\end{array}$ & $1223 \mathrm{AH}-1808 \mathrm{AD}$ & Osman Agha Street \\
\hline 5 & $\begin{array}{l}\text { Al-Amasiely } \\
\text { House }\end{array}$ & $1223 \mathrm{AH}-1808 \mathrm{AD}$ & Osman Agha Street \\
\hline 6 & Maki House & $1121 \mathrm{AH}-1709 \mathrm{AD}$ & $\begin{array}{l}\text { Tawahen Al-Talayet } \\
\text { street }\end{array}$ \\
\hline 7 & $\begin{array}{l}\text { Al-Manadely } \\
\text { House }\end{array}$ & 12th century AH & $\begin{array}{ll}\text { Al-Hag } & \text { Youssef } \\
\text { Street } & \\
\end{array}$ \\
\hline 8 & Thabet House & 12th century AH & $\begin{array}{l}\text { Al-shaikh Qandel } \\
\text { street }\end{array}$ \\
\hline 9 & Tabaq house & 12th century AH & $\begin{array}{l}\text { Al-shaikh Qandel } \\
\text { street }\end{array}$ \\
\hline 10 & $\begin{array}{l}\text { A-Qanadely } \\
\text { House }\end{array}$ & 12th century AH & $\begin{array}{l}\text { Al-shaikh Qandel } \\
\text { street }\end{array}$ \\
\hline 11 & $\begin{array}{l}\text { Al-Mezony } \\
\text { House }\end{array}$ & $1153 \mathrm{AH}-1740 \mathrm{AD}$ & Badr El-Deen Street \\
\hline 12 & $\begin{array}{l}\text { Al- Toqateley } \\
\text { House }\end{array}$ & 12th century AH & $\begin{array}{l}\text { Mohammed Koriem } \\
\text { street }\end{array}$ \\
\hline 13 & $\begin{array}{ll}\text { Al- } & \text { Gamal } \\
\text { House } & \\
\end{array}$ & 12th century AH & $\begin{array}{ll}\begin{array}{l}\text { Dehliez } \\
\text { street }\end{array} & \text { Al-Molk } \\
\end{array}$ \\
\hline 14 & $\begin{array}{l}\text { Ramadan } \\
\text { House }\end{array}$ & 12th century AH & $\begin{array}{ll}\begin{array}{l}\text { Dehliez } \\
\text { street }\end{array} & \text { Al-Molk } \\
\end{array}$ \\
\hline 15 & Elwan House & 12th century AH & $\begin{array}{ll}\begin{array}{l}\text { Dehliez } \\
\text { street }\end{array} & \text { Al-Molk } \\
\end{array}$ \\
\hline 16 & $\begin{array}{l}\text { Maharem } \\
\text { House }\end{array}$ & 12th century AH & $\begin{array}{ll}\begin{array}{l}\text { Dehliez } \\
\text { street }\end{array} & \text { Al-Molk } \\
\end{array}$ \\
\hline 17 & $\begin{array}{l}\text { Abouhom } \\
\text { House }\end{array}$ & 12th century $\mathrm{AH}$ & $\begin{array}{l}\text { Dehliez } \\
\text { street }\end{array}$ \\
\hline 18 & Kohai House & 12th century $\mathrm{AH}$ & $\begin{array}{ll}\begin{array}{l}\text { Dehliez } \\
\text { street }\end{array} & \text { Al-Molk } \\
\end{array}$ \\
\hline 19 & Basyoni House & 12th century $\mathrm{AH}$ & $\begin{array}{l}\text { Dehliez Al-Molk } \\
\text { street }\end{array}$ \\
\hline 20 & Derah House & 12th century AH & $\begin{array}{ll}\text { Al-Hag } & \text { Youssef } \\
\text { Street } & \\
\end{array}$ \\
\hline 21 & Galal House & 12th century AH & Badr El-Deen Street \\
\hline 22 & $\begin{array}{l}\text { Arab } \\
\text { house }\end{array}$ & 12th century AH & Al-Gaish Street \\
\hline
\end{tabular}

TABLE 6

(LIST OF HERITAGE VARIOUS BUILDINGS IN ROSETTA (RESEARCHER))

\begin{tabular}{c||c||c||c} 
No. & Building Name & Construction Date & Location \\
\hline 1 & Qaitbay Citadel & 884 AH -1479 AD & $\begin{array}{c}\text { Rachid Tower } \\
\text { (North of Rachid) }\end{array}$ \\
\hline 2 & Hamam Azouz & 11 th century AH & $\begin{array}{c}\text { Al -Hadadeen } \\
\text { Market Street }\end{array}$ \\
\hline 3 & $\begin{array}{c}\text { Abou Al-Resh } \\
\text { Gate }\end{array}$ & 12 th century AH & $\begin{array}{c}\text { Railway station } \\
\text { street }\end{array}$ \\
& &
\end{tabular}

Models of heritage buildings in Rosetta. Check Figures 13 $\& 14$.

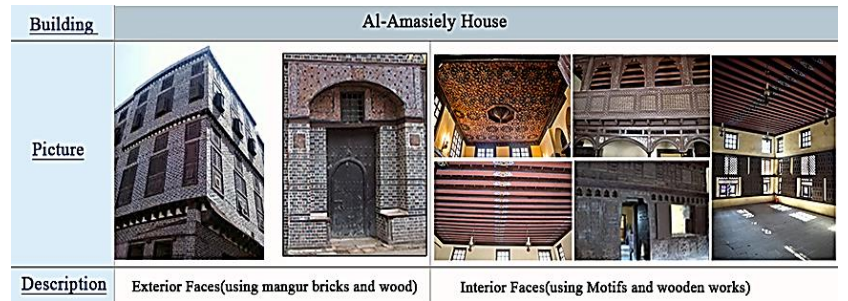

Figure 14 (Al-Amasiely House (10))

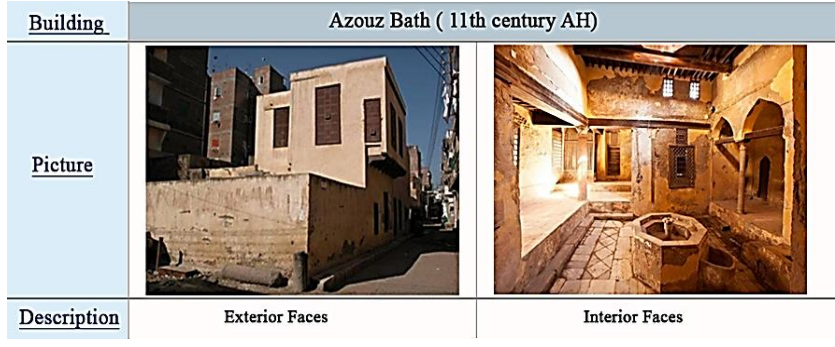

Figure 15 (Azouz bath Building (18))

The heritage buildings of Rosetta are multiplied between archaeological houses, mosques, and some unique buildings, and these buildings are characterized by a set of features (19):

- The use of red and black mangur bricks.

- Multi-layered composite wooden ceilings were also used as wooden cables to carry the protrusion of the facades.

- Reuse the columns of old buildings in the outer corners to carry the protrusion of facades or stairs and use them inside mosques as part of the construction system.

- Highlight the entrances to mosques using decorative units of mangur bricks.

\section{Results}

According to the analysis of the city of Rashid, both geographically and historically, it was found that there are some criteria of global importance related to the World Heritage Convention, as follows:

(ii) The city of Rashid offers an essential exchange of human values in specific periods of time during the Ottoman Islamic era and the resulting developments in architecture and the use of a distinct style of construction and the architectural elements that characterize Islamic architecture and city planning as well.

(iv) The heritage buildings in Rashid, such as residential houses, mosques, and other Islamic architecture buildings, bear witness to an essential period of time in human history.

(v) The city of Rashid is considered as being in its beginning as a war gap surrounded by high towers with a massive wall and a military castle and inside it a human settlement that has its character and distinctive features, which creates a unique identity and culture for it.

Not only that but a more comprehensive analysis of the city and a study of the impact of each of the nature that is there, the geography of the place. By studying man's influence with his culture in creating an urban environment in line with the natural environment and creating activities that distinguish this region from others. This effect was significantly observed. It became clear that Rashid's city is the product of these three interactions together, whether the human being with the surrounding nature and the place that gives the value and the time characteristic of human culture. This interaction left a group of activities that determined another heritage identity for the person and the place there. Check Figure 15. 


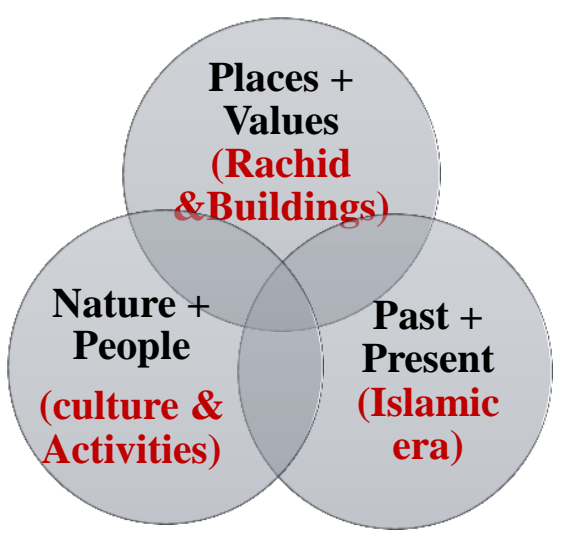

Figure 16The three aspects of Cultural Landscape in Rosetta (Researcher))

The city's historical identity resulted from a war gap in the beginning due to its location in its current geographical site. That reason made the residents build the towers, the castle, and the wall to protect the city and the Islamic conquest during this period. This created that type of building and Islamic buildings that reflect his cultures, such as mosques with courtyards, residential houses with broken entrances, and internal divisions of high privacy. Other establishments such as the Wekalah, public baths, and mills had a similar pattern in the construction of carved bricks and the intertwining of wood using various stone columns and other elements of Islamic architecture.

The research indicates that this conclusion corresponds to one of the three categories of world heritage cultural landscapes, the second paragraph of the second category. Check Figure 16.

The second category is the organically evolved landscape. This results from an initial social, economic, administrative, and/or religious imperative and has developed its present form by association with and in response to its natural environment. Such landscapes reflect that process of evolution in their form and component features. They fall into two sub-categories:

2 a relict (or fossil) landscape is one in which an evolutionary process came to an end at some time in the past, either abruptly or over a period. Its significant distinguishing features are, however, still visible in material form. a continuing landscape is one which retains an active social role in contemporary society closely associated with the traditional way of life, and in which the evolutionary process is still in progress. At the same time, it exhibits significant material evidence of its evolution over time.

Figure 17 (The second category of World heritage Cultural Landscape (7))

\section{Future research work}

Researchers in the field of heritage preservation and sustainability are also recommended to do more research related to heritage preservation in the city of Rashid, identify the risks that the city may be exposed to, and study opportunities that can help in conservation and development projects.

\section{RECOMMENDATIONS}

The research recommends dealing with the city of Rashid as mixed heritage and not just a cultural heritage. Therefore, preservation processes are not dealt with only on the building's scale to be restored but on the region.

The researcher recommends reconsidering the studies on Rosetta's city's tourism development and considering all the natural and heritage components while developing futuristic plans.

Those responsible for registering heritage areas on the World Heritage List must speed up the registration processes to speed up the processes of preserving these areas and increasing research and study efforts for the areas that can be nominated for registration on the World Heritage List.

Develop a tourist guide/map that features the touristic sites and the touristic services available in Rosetta city.

Develop a series of 'cultural heritage experience' hotspots that position Rosetta City as a destination of interest to international tourists.

Develop a database that includes all traditional crafts and locals interested in providing services to local and international tourists (peer-to-peer mentoring).

\section{AUTHORs CONTRIBUTION}

Basma Shaheen is responsible for data collection, tools and analysis, in addition to contributing to the drafting of the article as well as funding.

Mai Wahba Madkour is responsible for analyzing some data and contributed to the drafting of the article with supervision and periodic follow-up of the research.

Shahira Sayed Hasan is responsible for supervising and managing the work in addition to developing the methodology and making a cash back for the material

Ahmed Abd-Elwahab is responsible for designing the work with supervision and final approval of the copy to be published.

\section{REFERENCES}

[1] Rössler, M., 2003. Linking Nature and Culture: World Heritage Cultural Landscapes. Cultural landscapes: the challenges of conservation, p. 10.

[2] Azzam, Y., 2009. Planning strategy for Rosetta (Rosetta) 2027 - A case study, s.1.: General Organization for Physical Planning.

[3] Bandarin, F. \&. C. P. \&. R. M., 2002. Cultural landscapes: the challenges of conservation. World Heritage.

[4] Buggey, S., 1999. An approach to aboriginal cultural landscapes. s.1.: Historic Sites and Monuments Board of Canada, Ottawa.

[5] Darwish, A., 2017. Rosetta Encyclopedia Part II: Urban Heritage. s.1.: Arab Nation Publishing \& Distribution Est.

[6] Darwish, M. A., 1989. Monuments of Rosetta and its Wooden Antiques in the Ottoman Period, Faculty of Archeology, s.l.:Cairo University.

[7] Darwish, M. A., 2016. Preservation of the architectural heritage: Sultan Qayet-Bey Castle in Rosetta - Egypt. International Journal of Innovation and Applied Studies, Volume 18.

[8] El Banna, M. M., 2008. Vulnerability and fate of a coastal sand dune complex, Rosetta-Idku, northwestern Nile Delta, Egypt. Environmental geology, Volume 54.

[9] Fathy, H., 1986. Natural Energies and Vernacular Architecture, Mashrabiya (pp. 46-49). s.1.:Chicago, USA: The University of Chicago Press.

[10] Hegazi, Y. S. \& Fouda, M., 2019. Re-imaging Rosetta historic core through Space Syntax. Archnet-IJAR: International Journal of Architectural Research. 
[11] Lamei, S., 2006. Rosetta (Rosetta): A Mediterranean City: Past, Present I\& Future of a Living Heritage. s.l.:A PowerPoint presentation.< http://lib. teekerk. Gr/bitstream/lib. teekerk ....

[12] Madkour, M., 2018. Architectural Environmental Compatibility as an Approach to Conserve the Identity of Heritage Cities in Egypt Case Study: Rosetta City. International Journal of Environmental Science I\& Sustainable Development.

[13] Mitchell, N. \&. R. M. \&. P.-M., 2009. World Heritage Cultural Landscapes. A Handbook for Conservation and Management. s.1.: The UNESCO World Heritage Centre.

[14] Ray, J., 2007. The Rosetta stone and the rebirth of ancient Egypt. s.1.: Harvard University Press.

[15] RUSPS, 2006. Rapid Urban Sector Profiling for Sustainability (RUSPS), ROSETTA, s.l. s.n.

[16] RUSPS, 2006. Rosetta. UN-HABITAT-United Nations Human Settlements Program, s.l.: RUSPS.

[17] UNESCO, 2003. Tentative Lists. [Online] Available at: https://whc.unesco.org/en/tentativelists/1831//Accessed 118 2020].

[18] UNESCO, 2017. Basic Texts of the 1972 World Heritage Convention. s.1.: s.n.

[19] Google, 2020. Google Maps. [Online] Available at: https://goo.gl/maps/M9p7frdcZNF7YcS79 [Accessed 228 2020].

\section{Title Arabic:}

إعادة دراسة مدينة رشيد كمشهد ثقافى كخطوة للتسجيل على قائمة

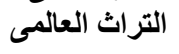

\section{Arabic Abstract:}

المدن كائنات ديناميكية. لا توجد مدينة "تاريخية" في العالم احتفظت بطابعها

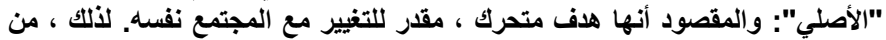

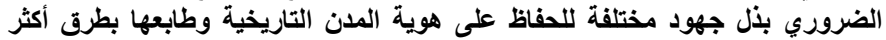

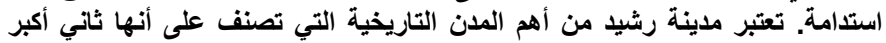

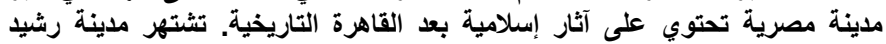

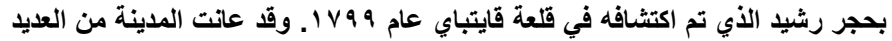

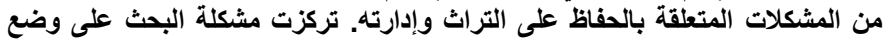

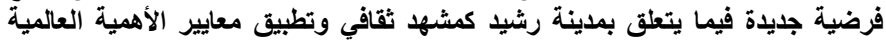

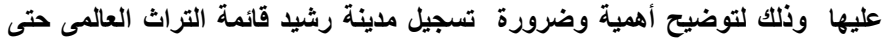

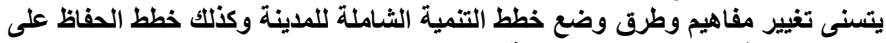

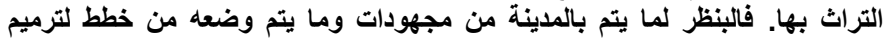

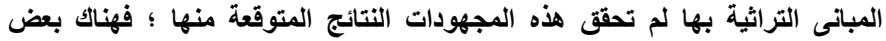

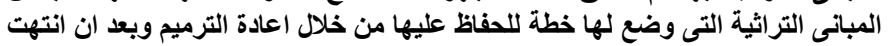

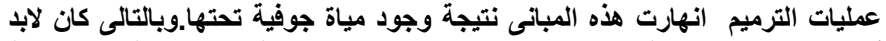

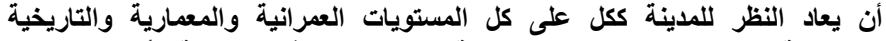

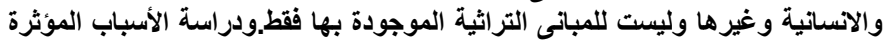

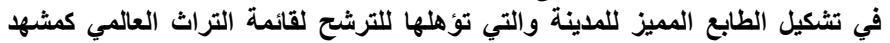

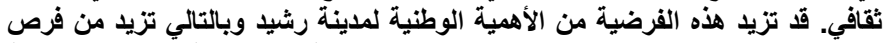

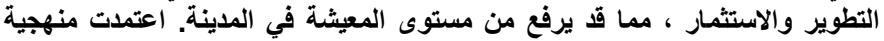

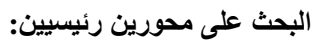
ا ـ المنهج التحليلي: ويشمل درينين دراسة آثار المكونات الطبيعية والتاريخية لرشيد

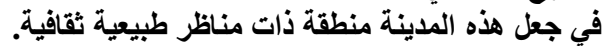

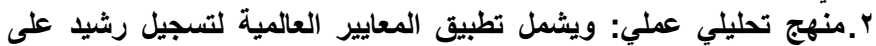

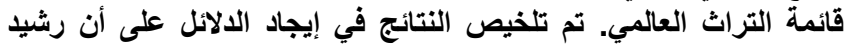

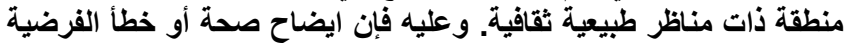

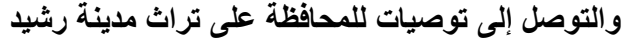

